\title{
Evaluating $\mathrm{HBsAg}$ rapid test performance for different biological samples from low and high infection rate settings \& populations
}

Helena Medina Cruz ${ }^{1}$, Leticia de Paula Scalioni ${ }^{1}$, Vanessa Salete de Paula ${ }^{2}$, Elisangela Ferreira da Silva ${ }^{1}$, Kycia Maria Rodrigues do Ó3 , Flavio Augusto Pádua Milagres ${ }^{4}$, Marcelo Santos Cruz ${ }^{5}$, Francisco Inácio Bastos ${ }^{6}$, Priscila Pollo-Flores ${ }^{7}$, Erotildes Leal ${ }^{8}$, Ana Rita Coimbra Motta-Castro ${ }^{9}$, José Henrique Pilotto ${ }^{10}$, Lia Laura Lewis-Ximenez ${ }^{1}$, Elisabeth Lampe ${ }^{1}$ and Livia Melo Villar ${ }^{1,11^{*}}$

\begin{abstract}
Background: Rapid tests (RTs) might have several advantages over standard laboratory procedures, increasing access to diagnosis, especially among vulnerable populations and/or those living in remote areas. The aim of this study was to evaluate the performance of RTs for the detection of hepatitis B virus surface antigen (HBsAg) in samples from different populations/settings.

Methods: Three RTs for HBsAg detection (Vikia ${ }^{\circledast} \mathrm{HBsAg}, \mathrm{HBsAg}$ Teste Rápido ${ }^{\circledast}$, and Imuno-Rápido HBsAg ${ }^{\oplus}$ ) and different biological specimens (serum, whole blood, and saliva) were evaluated. Analyses comprised a reference panel and samples from field studies targeting suspected cases of hepatitis B virus (HBV) (G I), individuals living in deprived areas (G II), and highly vulnerable individuals (G III). Enzyme immunoassay (EIA) was defined as the gold standard in this study. Reproducibility, repeatability, and cross-reactivity with other infectious agents such as dengue, immunodeficiency (HIV), and hepatitis $C$ (HCV) viruses and T. pallidum were determined.

Results: For the reference panel, the sensitivity and specificity of all HBsAg RTs were higher than $93.00 \%$. G I presented the highest kappa values for all rapid assays using sera samples. When using serum, the sensitivity values were higher than 93.40 for G I, $60.00 \%$ for G II and $66.77 \%$ for G III, and the specificity values were higher than 99.50 for $\mathrm{Gl}, 97.20$ for $\mathrm{G} I \mathrm{l}$ and 99.10 \% for G III for all tests. For whole blood samples \& the Vikia ${ }^{\circledR}$ HBsAg assay, the best performance was achieved for GIII ( $k=79.75 \%$ ). For saliva samples, the Imuno-Rápido HBsAg ${ }^{\oplus}$ assay showed the highest concordance values with EIA for G I (40.68 \%) and G II (32.20 \%). The reproducibility and repeatability of all RTs for serum and saliva were excellent, and the concordance between HBsAg EIAs and RTs using samples reactive with other infectious agents varied from $70.10 \%$ to $100.00 \%$.

(Continued on next page)
\end{abstract}

\footnotetext{
* Correspondence: liviafiocruz@gmail.com

'Laboratory of Viral Hepatitis, Oswaldo Cruz Institute, FIOCRUZ, Rio de Janeiro, Brazil

${ }^{11}$ Present address: Viral Hepatitis Laboratory, Helio and Peggy Pereira

Pavilion - Ground, Floor - Room B09, FIOCRUZ Av. Brazil, 4365 - Manguinhos,

Rio de Janeiro, RJ 210360-040, Brazil

Full list of author information is available at the end of the article
}

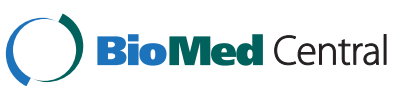

(c) 2015 Cruz et al. Open Access This article is distributed under the terms of the Creative Commons Attribution 4.0 International License (http://creativecommons.org/licenses/by/4.0/), which permits unrestricted use, distribution, and reproduction in any medium, provided you give appropriate credit to the original author(s) and the source, provide a link to the Creative Commons license, and indicate if changes were made. The Creative Commons Public Domain Dedication waiver (http://creativecommons.org/publicdomain/zero/1.0/) applies to the data made available in this article, unless otherwise stated. 
(Continued from previous page)

Conclusions: The overall performance of RTs for HBsAg in serum was high/moderately high for all groups, thereby promoting increased access to HBV diagnosis among vulnerable populations as well as samples from individuals in emergency settings or remote areas. Rapid tests for HBsAg using whole blood could be used in prevalence studies, though these assays should not be used for saliva samples.

Keywords: Hepatitis B virus, Rapid tests, Performance of tests, Diagnostic procedures

\section{Background}

Exposure to hepatitis B virus (HBV) may result in acute and chronic infections. Two billion individuals are estimated to have had contact with the virus and 240 million to be chronic carriers of HBV. Every year, approximately 600 thousand people die due to late complications of HBV infection [1].

Standard HBV diagnosis consists of the use of enzyme immunoassays (EIAs) and electrochemiluminescence (ECLIA) with serum or plasma samples [2]. However, these assays have limitations that may compromise their routine use in low- and middle-income countries: they require trained personnel as well as the availability of all necessary infrastructures. As an alternative, rapid tests (RTs) may have several advantages over standard procedures because they are easy to perform and can provide conclusive results within a few minutes. Additionally, these tests may be performed on a case-by-case basis and do not require laboratory infrastructure. Moreover, only minimal training is required to perform RTs [3-5].

Rapid tests for detection of the surface antigen of the hepatitis B virus (HBsAg) utilize a lateral flow device. Different approaches can be used in lateral flow assays, but in general, the patient's sample is poured over a membrane containing two areas: the first contains antibodies against HBsAg (anti-HBs) for detection; and the second, the control area, contains a set of reagents that represents the quality control of the conjugate [4].

HBsAg RTs have been used for HBV clinical diagnosis and in serosurveys in different settings and countries [4-7]. In Brazil, although rapid tests for human immunodeficiency virus (HIV) and hepatitis C virus (HCV) have been widely used, as recommended by the Brazilian Ministry of Health (BMoH) $[8,9]$, no standard algorithm or guideline is yet available for HBV RTs. Before the implementation of rapid testing for HBV diagnosis, key parameters such as their sensitivity, specificity, crossreactivity, reproducibility, and repetitively should be thoroughly evaluated.

The determination of the accuracy of a rapid test compared to a "gold standard" diagnostic procedure, such as ELISA, is key to minimizing false positive or negative results, thus increasing access to accurate diagnosis in remote areas and/or emergency settings. The aim of this study was to evaluate the performance of three rapid tests for HBsAg detection using three different types of fluid from individuals in different populations/settings.

\section{Methods}

\section{Study population}

No comprehensive population-based serosurvey in Brazil on HBV has been implemented to date. Local/focal studies have highlighted infection rates in different segments of the general population, and different at-risk groups are deeply heterogeneous. A comprehensive panel of sera from different key groups was established by the authors. Although based on convenience samples, it intentionally targeted as many populations and settings as possible, from all over the country.

The reference panel comprised serum samples obtained from 393 individuals recruited between 2010 and 2012 at Fiocruz Viral Hepatitis Ambulatory (Oswaldo Cruz Institute, Rio de Janeiro, Brazil), a Brazilian Referral center for the diagnosis of viral hepatitis (types A, B, C, D and E). The inclusion criteria for this group were acute, chronic or suspected cases of hepatitis B infections, age of more than 18 years and signed informed consent. Samples from individuals under follow-up at the Fiocruz outpatient clinic were tested for HBsAg using two ELISA kits (HBsAg, Radim, Pomezia, Italy and ETI-MAK-4, Diasorin, Italy) and three rapid tests (Vikia HBsAg, Biomérieux, France; HBsAg Teste Rápido ${ }^{\circ}$, Doles, Brazil, and ImunoRápido HBsAg ${ }^{\circ}$, Wama, Brazil).

A field study was composed of three groups (I-III), with each participant providing serum, whole blood and/ or saliva. The serum samples were tested for HBsAg using one ELISA kit (ETI-MAK-4, Diasorin, Italy), and all biological samples were assayed for all RTs evaluated.

Group I (G I) comprised 371 individuals referred to Fiocruz Viral Hepatitis Ambulatory (Oswaldo Cruz Institute, Rio de Janeiro) from 2009 to 2013. Inclusion criteria were attendance at Fiocruz Viral Hepatitis Ambulatory, residing in underserved and impoverished areas in Rio de Janeiro City (capital of Rio de Janeiro State) and a suspected case of viral hepatitis infection. This group was considered the high-risk group.

Group II (G II) comprised 881 individuals living in three (of the five) Brazilian macro-regions (Southeast, North and Midwest) and belonging to the general 
population, among which HBV prevalence has been low in recent years. None of these individuals were recruited in viral hepatitis ambulatory care settings, and this group was considered to be a low risk for HBV. These samples were obtained from individuals living in Rio de Janeiro State (Petrópolis and Macaé cities), Tocantis State (Tocantinópolis city), and Mato Grosso do Sul State (the Pantanal region) in 2009-2013 and who agreed to be tested within the context of public campaigns aiming to increase viral hepatitis diagnosis and the prompt referral of infected patients for treatment and care. The individuals from Mato Grosso do Sul State lived in communities of the Pantanal region, up to $385 \mathrm{~km}$ far from Campo Grande City (Mato Grosso do Sul State), whereas other individuals lived up to $217 \mathrm{~km}$ far (by river transportation) from the city of Corumbá (Mato Grosso do Sul State). The individuals from Tocantins State lived in rural communities from Tocantinópolis, $30 \mathrm{~km}$ far away from the urban area of the city. Such individuals belong to socially isolated populations living in deprived, underserved communities.

The individuals from Rio de Janeiro State were employees from a private hospital located in Petrópolis city who belonged to the middle-class as well as individuals living in underprivileged communities of Macaé city. Petrópolis city is located in a mountain region, and Macaé city is situated in the northern region of Rio de Janeiro State.

Our aim in this study was to assess as many individuals as possible from remote areas and/or deprived communities, as well as a small subgroup of people from the middle-class stratum. This subgroup falls short of a population-based repository, but deliberate efforts were made to establish a pool as diverse as possible, focusing on underserved populations that could benefit the most from extended testing strategies.

Finally, Group III (G III) was composed of 251 vulnerable individuals, including 158 beauticians and 93 heavy users of crack cocaine from Rio de Janeiro State.

All study participants and/or their legal guardians consented and signed informed consent forms prior to enrollment. Ethical approval for the study was issued by the Oswaldo Cruz Foundation Ethics Committee. Laboratory results were promptly returned to the patients' physicians.

\section{Sample collection}

Whole blood and serum samples were collected by venipuncture using vacutainer tubes, with (BD Vacutainer ${ }^{\circledR}$ containing the anticoagulant EDTA) and without (BD SST II Advance ${ }^{\circ}$ ) additives, respectively. Saliva samples were collected using commercial collection devices (Salivette; Sarstedt, Germany) and were mixed with $1 \mathrm{ml}$ of transport buffer. Oral fluid samples were centrifuged $(1,400 \times \mathrm{g}$ for $10 \mathrm{~min}$ ) and stored at $-20{ }^{\circ} \mathrm{C}$ until assayed, as detailed elsewhere [10]. For the reference panel, only serum samples were assayed, whereas serum, whole blood and saliva the field studies were analyzed.

\section{HBsAg and HBV detection}

Serum samples from the reference panel were tested for HBsAg markers using two commercial EIAs (HBsAg, Radim, Pomezia, Italy and ETI-MAK-4, Diasorin, Italy) following the manufacturers' instructions. Only samples with concordant results defined by both assays were included in the study. Serum samples from the field study were assayed for HBsAg detection using a commercial EIA (HBsAg, Radim, Pomezia, Italy). All HBsAg-reactive samples in the EIA were retested in duplicate. All serum samples were assayed for total antibodies directed against the total core antigen (anti-HBc total) as well as anti-HBs using EIAs (Diasorin, Italy). Serum samples were also assayed for anti-HBc IgM, HBV "e" antigen ( $\mathrm{HBeAg}$ ) and antibodies against $\mathrm{HBeAg}$ (anti-HBe) using commercial EIAs and ECLIAs (Diasorin, Italy) when sufficient sample volume was available.

\section{Rapid test evaluation}

Three HBsAg rapid tests were evaluated: Vikia ${ }^{\circ} \mathrm{HBsAg}$ (Biomerieux, France), HBsAg Teste Rápido ${ }^{\circ}$ (Doles, Brazil), and Imuno-Rápido $\mathrm{HBsAg}^{\circ}$ (Wama, Brazil). All the RTs are approved by the Brazilian National Health Surveillance Agency (ANVISA), which is responsible for the regulation, control and supervision of products and services that involve risk to public health. Vikia ${ }^{\circ}$ HBsAg has CE IVD approval but does not have FDA approval or WHO registration. Imuno-Rápido $\mathrm{HBsAg}^{\circ}$ does not have FDA approval or WHO registration; such information is not available for $\mathrm{HBsAg}$ Teste Rápido ${ }^{\circ}$.

All three tests are qualitative tests based on immunochromatographic techniques for lateral association of monoclonal and polyclonal antibodies specific for HBsAg. The Vikia HBsAg allows the detection of the main $a d$ and ay subtypes in serum, plasma and whole blood by adding $75 \mu \mathrm{l}$ of each sample to the test platform. Capillary blood by fingerstick can also be used in this test.

According to the manufacturers' instructions, the analytical sensitivity of the RTs is less than or equal to $2 \mathrm{IU} /$ $\mathrm{ml}$ for Vikia ${ }^{\circ} \mathrm{HBsAg}$ and from $10 \mathrm{IU} / \mathrm{ml}$ for HBsAg Teste Rápido ${ }^{\circ}$ and Imuno-Rápido $\mathrm{HBsAg}{ }^{\circ}$.

Readings were available within $15 \mathrm{~min}$ (though for negative samples, it was necessary to wait up to $30 \mathrm{~min}$ to confirm the result). The Imuno-rápido $\mathrm{HBsAg}^{\circ}$ and $\mathrm{HBsAg}$ teste rápido ${ }^{\circ}$ tests allow the detection of $\mathrm{HBsAg}$ 
in serum samples, and both assays use 100 microliters of sample. The results can be assessed within $20 \mathrm{~min}$.

All procedures for rapid tests were performed according to the manufacturers' recommendations, except for the saliva samples, for which twofold increases in sample volume (i.e., $75 \mu \mathrm{l} \rightarrow 150 \mu \mathrm{l}$ and $100 \mu \mathrm{l} \rightarrow 200 \mu \mathrm{l}$ ) were adopted to increase the sensitivity of HBsAg detection. The manufacturers' recommendations do not include the analysis of saliva samples. However, previous attempts made by our research group with regard to hepatitis $C$ [11] were successful and motivated the current attempt. In the present study, we extended saliva analyses by incorporating HBsAg detection. Serum and saliva were assayed for all HBsAg RTs, and whole blood samples were evaluated using the Vikia $^{\circ}$ HBsAg test because it is the only test specifically designed for the latter.

\section{Reproducibility and repeatability}

To evaluate the reproducibility and repeatability of HBsAg rapid tests, four samples (2 serum and 2 saliva samples) were tested in eleven replicates, each by two different operators, for two consecutive days. One HBsAgreactive and another $\mathrm{HBsAg-non-reactive} \mathrm{serum} \mathrm{sample}$ by EIA were included. HBV-negative individuals donated saliva samples. These saliva samples were then diluted (1:1) with an HBV-reactive serum sample.

The HBsAg rapid testing procedures were similar to the procedures described above for serum and saliva. kappa statistics were used to cross-compare the results of rapid tests and EIA.

\section{Cross-reactivity studies}

Serum samples reactive for other infectious agents were included in the analysis to assess the cross-reactivity of the HBsAg rapid tests. Twenty serum samples reactive for dengue virus (five for each of the co-circulating serotypes: DENV-1, DENV-2, DENV-3 and DENV-4), 69 HIV-reactive serum samples, 49 Treponema pallidumreactive serum samples, and $137 \mathrm{HCV}$-reactive samples were included. HBsAg was assayed using commercial EIA (HBsAg One, RADIM) and HBsAg rapid tests (Vikia ${ }^{\circ}$ HBsAg; HBsAg Teste Rápido ${ }^{\circ}$, and ImunoRápido $\mathrm{HBsAg}^{\odot}$ ).

\section{Data analysis}

The data analysis comprised samples with well-defined serology. Indeterminate samples detected by EIA were excluded. Socio-demographic, epidemiological, clinical, EIA and rapid test results were entered into an Access ${ }^{\circ}$ database. Statistical analyses were performed using SPSS 20.0 for Windows (SPSS Inc., USA). Parameters associated with test performance were evaluated using GraphPad InStat Programs, version 3.01 (GraphPad Software, San
Diego, USA) and MedCalc, version 9.2.1.0 (MedCalc Software, Mari-akerke, Belgium).

The RT results were cross-compared with the EIA results, which was defined for the sake of this study as the gold standard. Analytic categories were defined as follows: true positive results (TP - positive in both tests), true negative results ( $\mathrm{TN}$ - negative in both tests), false positive results (FP - positive in RT and negative in commercial EIA), false negative results (FN - negative in RT and positive in commercial EIA).

The clinical sensitivity (Cs), specificity (S), positive predictive value (PPV), and negative predictive value (NPV) for each rapid test were evaluated, and their respective $95 \%$ confidence intervals $(95 \% \mathrm{CI})$ were calculated. Contingency tables and respective statistics were used to cross-compare findings from different testing procedures and populations/settings.

Concordance between the panel's results and the results from rapid tests was assessed by kappa statistics [12]. P-values (two-tailed) $<0.05$ were considered statistically significant.

\section{Results}

\section{HBsAg rapid test performance using reference panels}

The reference panel was composed of 393 individuals, 103 of which were HBsAg reactive (sera), whereas 290 samples did not show HBsAg according to EIAs. The mean age ( \pm standard deviation) of the patients was 40.32 years $( \pm 14.78)$, and most were female $(61.24 \%)$. HBsAg was detected in 101, 98 and 96 of the samples, with sensitivities of $98.06,95.15$ and $93.20 \%$ by Vikia ${ }^{\circ}$ HBsAg, Imuno-Rápido HBsAg ${ }^{\circ}$ and HBsAg Teste Rápido ${ }^{\circ}$, respectively (Table 1 ).

According to the three RT assays, HBsAg false negative serum samples had a low optical density/cut-off value ratio $(\mathrm{OD} / \mathrm{CO})$ by EIA when compared to $\mathrm{HBsAg}$ true positive samples (concise information about the analytical detection limits is available in Additional file 1: Web Appendix 1).

Most of the HBsAg-reactive samples also presented anti-HBc total, whereas anti-HBc and anti-HBs were not detected in most of the HBsAg-non-reactive samples, independent of the group studied (21.60 to $65.70 \%$ ). In addition, anti-HBc IgM, HBeAg, anti-HBe were most frequently detected in the reference panel and group I (the serological characteristics of HBV markers is available in Additional file 1: Web Appendix 2).

\section{HBsAg rapid test performance using field samples}

Overall, 3,273 biological samples were collected in the different field studies, and 1,503 serum, 1,268 whole blood and 502 saliva samples were included in the analyses. The mean age of the individuals was 32.63 $( \pm 18: 43)$ years, $34.89( \pm 12.95)$ years and $34.06( \pm 16: 15)$ 
Table 1 Accuracy metrics (point estimates and 95\%Cls) of three rapid tests compared to results of HBsAg One ${ }^{\oplus}$ and ETI-MAK-4 ${ }^{\circledR}$, enzyme immunoassays

\begin{tabular}{|c|c|c|c|c|c|c|c|c|c|}
\hline Manufacturer & TP & $\mathrm{FN}$ & TN & $\mathrm{FP}$ & Sensitivity & Specificity & PPV & NPV & $\mathrm{K}(\mathrm{Cl} \%)$ \\
\hline \multicolumn{10}{|c|}{ HBsAg non-reactive/HBsAg reactive $(n=393)$} \\
\hline Vikia $H B s A g^{\oplus}$ & 101 & 2 & 290 & 0 & $98.06 \%(93.16-99.76)$ & $100.00 \%(98.74-100.00)$ & $100.00 \%(96.42-100.00)$ & $99.32 \%(97.54-99.92)$ & $98.68 \%(96.85-100.00)$ \\
\hline Imuno-Rápido HBsAg ${ }^{\oplus}$ & 98 & 5 & 287 & 3 & $95.15 \%(89.03-98.40)$ & $98.97 \%(97.01-99.79)$ & 97.03 (91.58-99.38) & $98.29 \%(96.05-99.44)$ & $94.7 \%(91.07-98.33)$ \\
\hline HBsAg teste rápido ${ }^{\oplus}$ & 96 & 7 & 287 & 3 & $93.20 \%(86.51-97.22)$ & $98.97 \%(97.01-99.79)$ & $96.97 \%(91.39-99.37)$ & $97.62 \%(95.16-99.04)$ & $93.34 \%(89.26-97.42)$ \\
\hline
\end{tabular}
Legends: TP True positive, FN False negative, TN True negative, FP False positive, PPV Positive Predictive Value, NPV Negative Predictive Value, $k$ Kappa statistics, $n$ number of observations (biological samples), $a$ confidence interval 
years for those donating serum, whole blood and saliva, respectively. Most individuals were women (51.93\% for serum, $55.19 \%$ for whole blood, and $52.93 \%$ for saliva).

The number of serum, whole blood and saliva samples from the different groups can be summarized as follows: G I - 371, 108 and 185 individuals; G II - 881, 767 and 160 individuals; G III - 251, 393 and 157 individuals, respectively. Overall (all groups and serum samples), Vikia $\mathrm{HBsAg}^{\circ}$ presented the highest kappa value $(96.08 \%$ ), followed by HBsAg teste rápido ${ }^{\circ}(88.41 \%)$ and Imunorápido $\mathrm{HBsAg}^{\circ}(87.62 \%)$. The specificities of all RTs were higher than $97 \%$, and Vikia HBsAg presented the highest sensitivity (Table 2).

For serum samples from G I, the sensitivity was 93.41, 94.01, and $95.81 \%$ and specificity 99.51, 99.51, and $100.00 \%$ using $\mathrm{HBsAg}$ teste rápido ${ }^{\circ}$, Imuno-rápido $\mathrm{HBsAg}^{\circ}$ and Vikia $\mathrm{HBsAg}^{\oplus}$, respectively. For samples from G II, sensitivity was $60.00 \%$ for all tests, and specificity was 97.83, 97.26, and $99.89 \%$ for HBsAg teste rápido ${ }^{\circ}$ Imuno-rápido $\mathrm{HBsAg}^{\circ}$ and Vikia $\mathrm{HBsAg}^{\circ}$, respectively. With respect to G III, sensitivity was $66.77 \%$ for all tests, and specificity was 99.18 , 99.59, and $100.00 \%$ for $\mathrm{HBsAg}$ teste rápido ${ }^{\circ}$, Imuno-rápido $\mathrm{HBsAg}^{\circ}$ and Vikia $\mathrm{HBsAg}^{\circ}$, respectively.

As observed in the reference panel, HBsAg false negative samples, as defined by RTs, presented low values of OD/CO by EIA compared to true HBsAg-positive samples (Additional file 1 available in Web Appendix 1).

The Vikia $\mathrm{HBsAg}^{\oplus}$ test performed using whole blood samples presented the highest kappa value for G III (79.75 \%), followed by G I (72.7 \%). Concordance was not determined among the G II samples because the test could not detect true positives. Immuno-Rápido $\mathrm{HBsAg}^{\odot}$ demonstrated the highest kappa value with EIA for G I (40.68 \%) saliva samples, followed by G III (32.20\%). For G III samples, none of the available RTs could detect true HBsAg-positive samples; thus, a concordance value could not be calculated (Table 3 ).

\section{Reproducibility and repeatability}

Reproducibility and repeatability analyses comprised 528 tests (264 serum and 264 saliva samples). The HBsAg teste rápido ${ }^{\circ}$, Immuno-Rápido $\mathrm{HBsAg}^{\circ}$ and Vikia $\mathrm{HBsAg}^{\circ}$ assays exhibited a $100.00 \%$ kappa value for the EIA results for all samples (i.e., serum and saliva samples HBsAg reactive/non-reactive).

\section{Cross-reactivity with other infectious agents}

HIV-, dengue virus-, $\mathrm{HCV}$ - and T. pallidum-reactive samples were evaluated using $\mathrm{HBsAg}$ rapid tests and EIA. HBsAg-reactive results were found among eight HCV samples, nine T. pallidum samples, and 15 HIV samples using EIA. In contrast, no HBsAg-reactive sample was found among the DENV samples.
The kappa statistic for EIA and RTs for HBsAg detection varied from $76.60 \%$ to $85.10 \%$ for T. pallidum, $70.10 \%$ to 81.10 \% for HIV, 78.80 \% to $86.70 \%$ for HCV and $100 \%$ for dengue for all manufacturers. False negative results were found for all manufacturers for T. pallidum, HIV and HCV, and false positive results were found in one HIV-reactive sample (using HBsAg teste rápido ${ }^{\circ}$ ) and two $\mathrm{HCV}$-reactive samples (one by $\mathrm{HBsAg}$ teste rápido ${ }^{\circ}$ and the other by Immuno-Rápido $\mathrm{HBsAg}^{\circ}$ ) (Table 4).

\section{Discussion}

The present study demonstrates the usefulness of HBsAg rapid tests in both the lab and the field. All rapid tests detected HBsAg among serum samples from a reference panel, with high sensitivity and specificity within contexts of high background prevalence. However, sensitivity was found to be poor when the background prevalence was low. In the field study, HBsAg rapid tests demonstrated a higher than $96.00 \%$ specificity among serum samples, regardless of the manufacturer and the group under study, demonstrating the ability of these assays to detect HBsAg true negative samples [5, 12-15). The performance of RTs could be influenced by the antigen concentration because false negative samples had low average values of $\mathrm{OD} / \mathrm{CO}$ compared to true positive samples, in agreement with previous studies $[4,14]$.

In the present study, the presence of HBV markers, such as anti-HBc or anti-HBs, did not appear to influence the HBsAg RT results. However, it was not possible to evaluate all the samples for HBeAg, anti-HBe and/or anti-HBc IgM due to low sample volumes. Thus, it was not possible to evaluate the influence of these markers on the performance of HBsAg RT performance.

The Vikia $\mathrm{HBsAg}^{\ominus}$ test presented the best performance in both the laboratory and field for serum samples, and the highest concordance was observed among G I patients. Such optimal performance may be secondary to the high HBsAg prevalence in this group, as observed by Lien et al. [13] using RTs from other manufacturers. In Brazil, confirmed HBV cases from 1999 to 2011 (120.343) were most reported in the southeast region $(36.30 \%)$, where Rio de Janeiro is located (16).

Low HBsAg prevalence could influence the performance of rapid tests, as found for the G II and G III samples. In Brazil, the HBsAg prevalence varies from $0.63 \%$ in the northern region to $0.31 \%$ in both the southeastern and midwestern regions [16]. Previous studies conducted among beauticians and crack users showed a lower HBsAg prevalence of $0 \%$ to $6.2 \%$ in Rio de Janeiro [17, 18]. However, in the present study the prevalence in these groups was $2.3 \%$, corroborating the a priori assumption these groups are particularly vulnerable to $\mathrm{HBV}$ infection. 
Table 2 Accuracy metrics (point estimates and 95\%Cls) of three rapid tests compared to results obtained by enzyme immunoassay ETI-MAK-4 ${ }^{\circledR}$ in serum samples according to the characteristics of the study population

\begin{tabular}{|c|c|c|c|c|c|c|c|c|c|}
\hline Profile/Manufacturer (n) & TP & $\mathrm{FN}$ & $\mathrm{TN}$ & FP & Sensitivity & Specificity & PPV & NPV & K \\
\hline \multicolumn{10}{|l|}{ Group I } \\
\hline Vikia HBsAg ${ }^{\oplus}(371)$ & 160 & 7 & 204 & 0 & $95.81 \%(91.54-98.30)$ & $100.00 \%(98.21-100.00)$ & $100.00 \%(97.72-100.00)$ & 96.68 \% (93.30-98.65) & $96.17 \%$ (93.36-98,98) \\
\hline Imuno-rápido HBsAg® (371) & 157 & 10 & 203 & 1 & $94.01 \%(89.27-97.09)$ & 99.51 \% (97.30-99.99) & 99.37 \% (96.53-99.98) & 95.31 \% (91.53-97.72) & $93.98 \%$ (90.48-97.48) \\
\hline HBsAg Teste rápido ${ }^{\oplus}$ (371) & 156 & 11 & 203 & 1 & $93.41 \%(88.53-96.67)$ & 99.51 \% (97.30-99.99) & 99.36 \% (96.51-99.98) & $94.86 \%$ (90.99-97.41) & $93.43 \%$ (89.77-97.09) \\
\hline \multicolumn{10}{|l|}{ Group II } \\
\hline Vikia HBsAg ${ }^{\oplus}(881)$ & 3 & 2 & 875 & 1 & $60.00 \%(14.67-94.73)$ & $99.89 \%(99.37-100.00)$ & $75.00 \%$ (19.42-99.37) & 99.77 \% (99.18-99.97) & $66.50 \%(28.65-100.00)$ \\
\hline Imuno-rápido HBsAg ${ }^{\oplus}$ (881) & 3 & 2 & 852 & 24 & $60.00 \%(14.67-94.73)$ & 97.26 \% (95.94-98.24) & $11.11 \%$ (23.55-29.18) & $99.77 \%(99.16-99,97)$ & $17.96 \%(0.00-49.02)$ \\
\hline HBsAg Teste rápido ${ }^{\oplus}(881)$ & 3 & 2 & 857 & 19 & $60.00 \%(14.67-94.73)$ & 97.83 \% (96.63-98.69) & 13.64 \% (29.04-34.94) & $99.77 \%(99,16-99.97)$ & $21.50 \%(0.00-54.67)$ \\
\hline \multicolumn{10}{|l|}{ Group III } \\
\hline Vikia HBsAg ${ }^{\oplus}(251)$ & 4 & 2 & 245 & 0 & $66.67 \%(22.27-95.67)$ & $100.00 \%(98.51-100.00)$ & $100.00 \%(39.76-100.00)$ & 99.19 \% (97.11-99.90) & $79.61 \%$ (51.46-100.00) \\
\hline Imuno-rápido HBsAg ${ }^{\oplus}$ (251) & 4 & 2 & 244 & 1 & $66.67 \%(22.27-95.67)$ & 99.59 \% (97.75-99.99) & $80.00 \%$ (28.35-99.49) & 99.19 \% (97.11-99.90) & $72.12 \%(40.76-100.00)$ \\
\hline HBsAg Teste rápido ${ }^{\oplus}(251)$ & 4 & 2 & 243 & 2 & $66.67 \%(22.27-95.67)$ & 99.18 \% (97.08-99.90) & $66.67 \%$ (22.27-95.67) & $99.19 \%(97.11-99.90)$ & $65.85 \%$ (32.65-99.05) \\
\hline \multicolumn{10}{|l|}{ Overall } \\
\hline Vikia HBsAg ${ }^{\oplus}(1503)$ & 167 & 11 & 1324 & 1 & $93.82 \%(89.21-96.87)$ & $99.92 \%(99.58-100.00)$ & $99.40 \%$ (96.73-99.98) & 99.18 \% (98.53-99.59) & 96.08 \% (93.87-98.29) \\
\hline Imuno-rápido HBsAg ${ }^{\oplus}$ (1503) & 164 & 14 & 1299 & 26 & $92.13 \%(87.14-95.63)$ & $98.04 \%$ (97.14-98.71) & 86.32 \% (80.57-90.86) & $98.93 \%(98.21-99.42)$ & $87.62 \%$ (83.83-91.41) \\
\hline HBsAg Teste rápido® (1503) & 163 & 15 & 1303 & 22 & $91.57 \%(86.50-95.21)$ & 98.34 \% (97.49-98.96) & $88.11 \%(82.57-92.39)$ & 98.86 \% (98.13-99.36) & $88.41 \%$ (84.72-92.1) \\
\hline
\end{tabular}

Legends: TP True positive, FN False negative, TN True negative, FP False positive, PPV Positive Predictive Value, NPV Negative Predictive Value, $k$ kappa statistics, $n$ number of samples, $C I$ confidence interval 
Table 3 Kappa statistics and positive and negative samples detected by rapid tests using saliva (3) and whole blood (1) samples compared to results obtained using respective serum samples by enzyme immunoassay ETI-MAK-4 ${ }^{\circledR}$ according to the characteristics of the population under analysis

\begin{tabular}{|c|c|c|c|c|c|}
\hline Profile/Manufactory - Biological specimen & $\mathrm{TP}$ & FN & TN & FP & K \\
\hline \multicolumn{6}{|l|}{ Group I } \\
\hline Vikia $\mathrm{HBsAg}^{\oplus}$ - SALIVA & 6 & 76 & 101 & 2 & $5.92 \%(0.00-21.8)$ \\
\hline Imuno-Rápido HBsA ${ }^{\oplus}$ - SALIVA & 33 & 49 & 101 & 2 & $40.68 \%(26.82-54.54)$ \\
\hline Teste rápido $\mathrm{HBsAg}^{\oplus}$ - SALIVA & 2 & 80 & 101 & 2 & $0.55 \%(0.00-16.61)$ \\
\hline Vikia HBsAg ${ }^{\oplus}$ - WHOLE BLOOD & 18 & 10 & 80 & 0 & $72.73 \%(56.63-88.83)$ \\
\hline \multicolumn{6}{|l|}{ Group II } \\
\hline Vikia $\mathrm{HBsAg}^{\oplus}$ - SALIVA & 0 & 2 & 153 & 5 & a \\
\hline Imuno-Rápido HBsA ${ }^{\oplus}$ - SALIVA & 1 & 1 & 155 & 3 & $32.2 \%(0.00-97.8)$ \\
\hline Teste rápido $\mathrm{HBsAg}^{\oplus}$ - SALIVA & 0 & 2 & 158 & 0 & a \\
\hline Vikia $\mathrm{HBsAg}^{\oplus}$ - WHOLE BLOOD & 0 & 3 & 763 & 1 & a \\
\hline \multicolumn{6}{|l|}{ Group III } \\
\hline Vikia HBsAg ${ }^{\oplus}$ - SALIVA & 0 & 4 & 153 & 0 & a \\
\hline Imuno-Rápido HBsA ${ }^{\oplus}$ - SALIVA & 0 & 4 & 149 & 4 & a \\
\hline Teste rápido HBsAg ${ }^{\oplus}$ - SALIVA & 0 & 4 & 150 & 3 & a \\
\hline Vikia HBsAg ${ }^{\oplus}$ - WHOLE BLOOD & 4 & 2 & 387 & 0 & $79.75 \%(51.76-100.00)$ \\
\hline \multicolumn{6}{|l|}{ Overall } \\
\hline Vikia $\mathrm{HBsAg}^{\oplus}$ - SALIVA & 6 & 82 & 407 & 7 & $7.72 \%(0,00-25,11)$ \\
\hline Imuno-Rápido HBsA ${ }^{\oplus}$ - SALIVA & 34 & 54 & 405 & 9 & $45.65 \%(33.1-58.2)$ \\
\hline Teste rápido HBsAg ${ }^{\oplus}$ - SALIVA & 2 & 86 & 409 & 5 & $1.67 \%(0.00-19.95)$ \\
\hline Vikia HBsAg ${ }^{\oplus}$ - WHOLE BLOOD & 22 & 15 & 1230 & 1 & $72.72 \%$ (59.44-86.00) \\
\hline
\end{tabular}

Legend: TP True positive, FN False negative, TN True negative, FP False positive, $k$ kappa statistics, $n$ number of observations (biological samples), $C l$ confidence interval a not amenable to calculation

The best performance of the Vikia $\mathrm{HBsAg}^{\circ}$ test in whole blood samples was observed in the G III samples, favoring the applicability of this rapid test to vulnerable individuals. Nonetheless, the kappa value was relatively low $(72.73 \%)$ compared to a previous study conducted in France (96.98 \%) [4]. The observed difference may be secondary to different blood collection procedures: blood was obtained by venipuncture in tubes without anticoagulant in the previous study [4] yet by venipuncture in tubes with anticoagulant in the present study.

The best performance for saliva samples was achieved using the Immuno-Rápido $\mathrm{HBsAg}^{\circ}$ assay in the G I and II samples. However, a high number of false negative results were observed for the tests from all manufacturers, regardless of the group under study, which is most likely secondary to the low concentration of HBsAg in saliva samples [19]. In addition, HBsAg rapid tests were not originally developed for saliva samples, which may also explain the low concordance with EIA results.

Accordingly, our findings must be viewed as a warning against the use of these procedures for $\mathrm{HBsAg}$ detection in saliva samples. The previous promising findings respecting hepatitis $C$ testing were, unfortunately, not observed for HBsAg.
In the present study, the volume of saliva sample was increased in all rapid tests to improve the sensitivity of the assay, but this procedure could not be translated into concrete benefits. Additional modifications, such as a longer incubation period, may be pursued by future studies.

The HBsAg rapid tests demonstrated excellent repeatability and reproducibility in serum and artificially contaminated saliva samples, demonstrating the good performance of these assays under laboratory conditions.

Although two meta-analysis studies showed high pooled accuracy for RTs for HBsAg [20, 21], Khuroo et al. [21] also observed wide variation in sensitivity among individual tests (43.5\% to $99.8 \%$ ), which could be due to the design of the studies or population characteristics because the performance of RTs are better in developed than in developing countries. In the present study, a wide variation of sensitivity of RTs for HBsAg was observed according to the group studied ( $60.00 \%$ to $95.81 \%$ ), demonstrating the importance of evaluating RTs among specific populations before implementation at a large scale.

Regarding cross-reactivity, the best results using serum samples were found among reactive dengue samples, most likely due to the absence of HBsAg-reactive samples 
Table 4 Kappa statistics and positive and negative samples detected by HBsAg rapid tests among serum samples with reactive serology for different infections compared to results obtained by enzyme immunoassay ETI-MAK-4 ${ }^{\circledR}$

\begin{tabular}{|c|c|c|c|c|c|}
\hline & $\mathrm{TP}(\mathrm{n})$ & FN (n) & $\mathrm{FP}(\mathrm{n})$ & TN (n) & K\% (IC\%) \\
\hline \multicolumn{6}{|l|}{ Dengue $(n=20)$} \\
\hline Vikia HBsAg ${ }^{\circledast}$ & 0 & 0 & 0 & 20 & $100.00 \%$ \\
\hline Imuno-Rápido HBsAg ${ }^{\oplus}$ & 0 & 0 & 0 & 20 & $100.00 \%$ \\
\hline Teste rápido $\mathrm{HBsAg}^{\circledast}$ & 0 & 0 & 0 & 20 & $100.00 \%$ \\
\hline \multicolumn{6}{|l|}{ T. pallidum $(n=49)$} \\
\hline Vikia HBsAg ${ }^{\circledast}$ & 7 & 2 & 0 & 40 & $85.10 \%$ \\
\hline Imuno-Rápido HBsAg ${ }^{\oplus}$ & 6 & 3 & 0 & 40 & $76.60 \%$ \\
\hline Teste rápido $\mathrm{HBsAg}^{\oplus}$ & 7 & 2 & 0 & 40 & $85.10 \%$ \\
\hline \multicolumn{6}{|l|}{ HIV $(n=69)$} \\
\hline Vikia $\mathrm{HBsAg}^{\oplus}$ & 11 & 4 & 0 & 54 & $81.10 \%$ \\
\hline Imuno-Rápido HBsAg ${ }^{\oplus}$ & 9 & 6 & 0 & 54 & $70.10 \%$ \\
\hline Teste rápido $\mathrm{HBsAg}^{\oplus}$ & 11 & 4 & 1 & 53 & $77.00 \%$ \\
\hline \multicolumn{6}{|l|}{$\mathrm{HCV}(n=137)$} \\
\hline Vikia HBsAg ${ }^{\oplus}$ & 6 & 2 & 0 & 129 & $85.00 \%$ \\
\hline Imuno-Rápido HBsAg ${ }^{\oplus}$ & 6 & 2 & 1 & 128 & $78.80 \%$ \\
\hline Teste rápido $\mathrm{HBsAg}^{\circledast}$ & 7 & 1 & 1 & 128 & $86.70 \%$ \\
\hline
\end{tabular}

Legend: TP True positive, FN False negative, TN True negative, FP False positive, $k$ kappa statistics, $n$ number of observations (biological samples), $C l$ confidence interval

and/or the low number of dengue samples under analysis (i.e., due to beta error). Regardless, for T. pallidum-, HIVand $\mathrm{HCV}$-reactive samples, false negative and positive HBsAg results were observed for all RTs. However, the poorest performance was observed among HIV-reactive samples. This is of concern because under real life conditions, a non-negligible fraction of patients may be co-infected by the two viruses, which may yield confusing results and inconclusive clinical interpretations.

The Vikia $\mathrm{HBsAg}^{\circ}$ and $\mathrm{HBsAg}$ teste rápido ${ }^{\circ}$ tests showed better kappa values for HIV- and HCV-reactive samples, respectively, and both Vikia $\mathrm{HBsAg}^{\oplus}$ and HBsAg teste rápido ${ }^{\circ}$ showed better kappa values for $T$. pallidum-reactive samples. These results suggest that both assays may have good performance with samples reactive for other infections. Other HBsAg RTs presented good performance among HIV-reactive samples $[6,7]$. In addition, a meta-analysis demonstrated that co-infections (for example HIV, HCV, tuberculosis) did not influence the diagnostic accuracy of HBsAg RTs, which could be helpful for the adoption of these assays in endemic areas where these co-infections are highly prevalent [21].

This study presents some limitations, such as the absence of HBsAg neutralization, HBV DNA testing or $\mathrm{HBsAg}$ concentration due to low sample volume. However, reactive HBsAg samples were retested in duplicate to confirm the HBsAg results.

\section{Conclusion}

In conclusion, the present study showed moderate to high concordance of HBsAg rapid tests using serum samples from different populations/settings. These findings could be useful for HBV diagnosis among individuals who are highly vulnerable to HBV infection as well as those recruited from emergency settings or remote areas. In addition, saliva samples should not be used for HBsAg detection with the assays evaluated in the present study.

\section{Additional file}

Additional file 1: Appendix 1. Mean values of OD/CO from ElE among false negatives and true positive rapid tests for $\mathrm{HBsAg}$ detection in three rapid tests according to the characteristics of the study population. Appendix 2. HBV markers (anti-HBC, anti-HBs, anti-HBC IgM, HBeAg, anti-HBe) detected in serum samples using enzyme immunoassay according to the population studied. (DOC $63 \mathrm{~kb}$ )

\section{Abbreviations \\ Anti-HBC IgM: Antibodies directed against the core antigen IgM; Anti-HBC total: Antibodies directed against the core antigen; Anti-HBe: Antibodies against HBeAg; ANVISA: National Health Surveillance Agency; Anti-HBs: Antibodies directed against hepatitis B surface antigen; $\mathrm{BMoH}$ : Brazilian Ministry of Health; Cl: Confidence interval; CO: Cut-off value; Cs: Clinical sensitivity; ECLIA: Electrochemiluminescence; EIA: Enzyme immunoassay; FDA: Food and drug administration; FN: False negative result (negative in RT and positive in commercial EIA); FP: False positive result (positive in RT and negative in commercial EIA); HBeAg: HBV "e" antigen; HBsAg: Surface antigen of the hepatitis B virus; HBV: Hepatitis B virus; HCV: Hepatitis C virus; HIV: Human immunodeficiency virus; NPV: Negative predictive value; OD: Optical density; PPV: Positive predictive value; S: Specificity; TN: True negative result (negative in both RT and EIA); TP: True positive result (positive in both RT and EIA).}

\section{Competing interests}

The authors disclose no actual or potential conflict of interest, including any financial, personal or other relationships with people or organizations, within two years of the beginning of this study that could inappropriately influence the study.

\section{Authors' contributions}

LMV and EL conceived the study; LMV, HMC and EL designed the study protocol; LLLX, MSC, FIB, KMRO, FAPM, PPF, ErL, ARCMC, JHP carried out the clinical assessment, subject selection and recruitment; HMC, LPS, VSP, EFS, LMV performed the rapid tests, immunoassays, and analysis and interpretation of these data; LMV, HMC, FIB drafted the manuscript; FIB, VSP, LMV, LLLX, EL critically revised the manuscript for intellectual content. All authors read and approved the final manuscript.

\section{Acknowledgments}

The authors wish to thank Juliana Custódio Miguel, Renata Tourinho dos Santos, Jaqueline Correia de Oliveira for technical assistance in the sample collection.

This research was supported by the Support Foundation for Research in Rio de Janeiro State (FAPERJ), Brazilian National Council of Technological and Scientific Development (CNPq) and the Oswaldo Cruz Foundation (FIOCRUZ).

\section{Author details}

${ }^{1}$ Laboratory of Viral Hepatitis, Oswaldo Cruz Institute, FIOCRUZ, Rio de Janeiro, Brazil. '2Laboratory of Technological Development of Virology, Oswaldo Cruz Institute, FIOCRUZ, Rio de Janeiro, Brazil. ${ }^{3}$ São Lucas Hospital, Petropolis, Rio de Janeiro, Brazil. ${ }^{4}$ Medicine Faculty, Federal University of Tocantins, Palmas, Brazil. ${ }^{5}$ Institute of Psychiatry, Federal University of Rio de 
Janeiro, Rio de Janeiro, Brazil. ${ }^{6}$ Institute of Communication and Scientific Information \& Technology for Health, Oswaldo Cruz Foundation, Rio de Janeiro, Brazil. ${ }^{7}$ Antonio Pedro University Hospital, Federal Fluminense University, Rio de Janeiro, Brazil. ${ }^{8}$ Federal University of Rio de Janeiro, Campus Macaé, Rio de Janeiro, Brazil. ${ }^{9}$ Federal University of Mato Grosso do Sul and FIOCRUZ-MS, Campo Grande, MS, Brazil. ${ }^{10}$ Laboratory of AIDS and Molecular Immunology, Oswaldo Cruz Institute, FIOCRUZ, Rio de Janeiro, Brazil. ${ }^{11}$ Present address: Viral Hepatitis Laboratory, Helio and Peggy Pereira Pavilion - Ground, Floor - Room B09, FIOCRUZ Av. Brazil, 4365 - Manguinhos, Rio de Janeiro, RJ 210360-040, Brazil.

Received: 23 May 2015 Accepted: 28 October 2015

Published online: 30 November 2015

\section{References}

1. World Health Organization. Hepatitis B. 2014. http://www.who.int/ mediacentre/factsheets/fs204/en/ [Accessed on 22.11.14].

2. Gerlich WH. Medical Virology of Hepatitis B: how it began and where we are now. Virol J. 2013;10:239.

3. Seremba E, Ocama P, Opio CK, Kagimu M, Yuan HJ, Attar N, et al. Validity of the rapid strip assay test for detecting Hbsag in patients admitted to hospital in Uganda. J Med Virol. 2010;82:1334-40.

4. Bottero J, Boyd A, Gozlan J, Lemoine M, Carrat F, Collignon A, et al. Performance of rapid tests for detection of $\mathrm{HBsAg}$ and Anti-HBsAb in a large cohort. France J Hepatol. 2013;58:473-8.

5. Chevaliez S, Challine D, Naija H, Luu TC, Laperche S, Nadala L, et al. Performance of a new rapid test for the detection of hepatitis $B$ surface antigen in various patient populations. J Clin Virol. 2014;59:89-93.

6. Davies J, van Oosterhout JJ, Nyirenda M, Bowden J, Moore E, Hart IJ, et al. Reliability of rapid testing for hepatitis $B$ in a region of high HIV endemicity. Trans R Soc Trop Med Hyg. 2010;104:162-4.

7. Franzeck FC, Ngwale R, Msongole B, Hamisi M, Abdul O, Henning L, et al. Viral hepatitis and rapid diagnostic test based screening for HBsAg in HIV-infected patients in rural Tanzania. PLoS One. 2013;8(3), e58468.

8. Brazilian Health Ministry. Technical manual for diagnosis of HIV infection. 2014. http://www.aids.gov.br/sites/default/files/anexos/publicacao/2013/ 55594/_p_manual_tecnico_hiv_final_pdf_p_23462.pdf. [Accessed on 29.11.14].

9. Brazilian Health Ministery. Include and change procedures of procedures table, Drugs, Orthotics, Prosthetics and Specialty Materials for SUS. Ordinance $n .{ }^{\circ} 730$ from July $02^{\text {nd }}$ 2013. 2013. http://bvsms.saude.gov.br/bvs/ saudelegis/sas/2013/prt0730_02_07_2013.html. [Accessed on 22.11.14].

10. Cruz HM, da Silva EF, Villela-Nogueira CA, Nabuco LC, KM d Ó, Lewis-Ximenez LL, et al. Evaluation of saliva specimens as an alternative sampling method to detect hepatitis B surface antigen. J Clin Lab Anal. 2011;25:134-41.

11. Scalioni Lde P, Cruz HM, de Paula VS, Miguel JC, Marques VA, Villela-Nogueira CA, et al. Performance of rapid hepatitis C virus antibody assays among high- and low-risk populations. J Clin Virol. 2014;60(3):200-5.

12. Altman DG. Practical Statistics for Medical Research. London: Chapman and Hall; 1991.

13. Lien TX, Tien NT, Chanpong GF, Cuc CT, Yen VT, Soderquist R, et al. Evaluation of rapid diagnostic tests for the detection of human immunodeficiency virus types 1 and 2, hepatitis B surface antigen, and syphilis in Ho Chi Minh City, Vietnam. Am J Trop Med Hyg. 2000;62:301-9.

14. Martínez-Lamas L, Rodríguez JJ, Regueiro BJ, Aguilera A. Evaluación de um test rápidominmunocromatográfico para la detección del antígeno de superficie de la hepatitis B. Rev Esp Quimioter. 2011;24:164-5.

15. Randriamina F, Carod JF, Ratsima E, Chrétien JB, Richard V, Talarmin A. Evaluation of the performace of four rapid tests for detection of hepatitis $B$ surface antigen in Antananarivo, Madagascar. J Virol Methods. 2008;151:294-7.

16. Brazilian Health Ministry. Secretariat of Health Surveillance. STD, Aids and Viral Hepatitis Department. Epidemiological Bulletin - Viral Hepatitis. 2012. http://www.aids.gov.br/sites/default/files/anexos/publicacao/2012/ 51820/boletim_epidemiol_gico_hepatites_virais_2012_ve_12026.pdf. [Accessed on 29.11.14].

17. Santos Cruz M, Andrade T, Bastos Fl, Leal E, Bertoni N, Villar LM, et al. Key drug use, health and socio-economic characteristics of young crack users in two Brazilian cities. Int J Drug Policy. 2013;24:432-8.
18. Villar LM, de Paula VS, de Almeida AJ, KM d Ó, Miguel JC, Lampe E. Knowledge and prevalence of viral hepatitis among beauticians. J Med Virol. 2014;86:1515-21.

19. Parry JV, Perry KR, Mortimer PP. Sensitive tests for viral antibodies in saliva; an alternative to tests on serum. Lancet. 1987;2:72-5.

20. Shivkumar $S$, Peeling $R$, Jafari $Y$, Joseph $L$ and Pai NP. Rapid Point-of-Care First-Line Screening Tests for Hepatitis B Infection: A Meta-Analysis of Diagnostic Accuracy (1980-2010). Am J Gastroenterol advance online publication, 2012; doi: 10.1038/ajg.2012.141.

21. Khuroo MS, Khuroo NS, Khuroo MS. Accuracy of rapid point-of-care diagnostic tests for hepatitis b surface antigen - a systematic review and meta-analysis. J Clin Exp Hepatol. 2014;4(3):226-40.

\section{Submit your next manuscript to BioMed Central and take full advantage of:}

- Convenient online submission

- Thorough peer review

- No space constraints or color figure charges

- Immediate publication on acceptance

- Inclusion in PubMed, CAS, Scopus and Google Scholar

- Research which is freely available for redistribution 